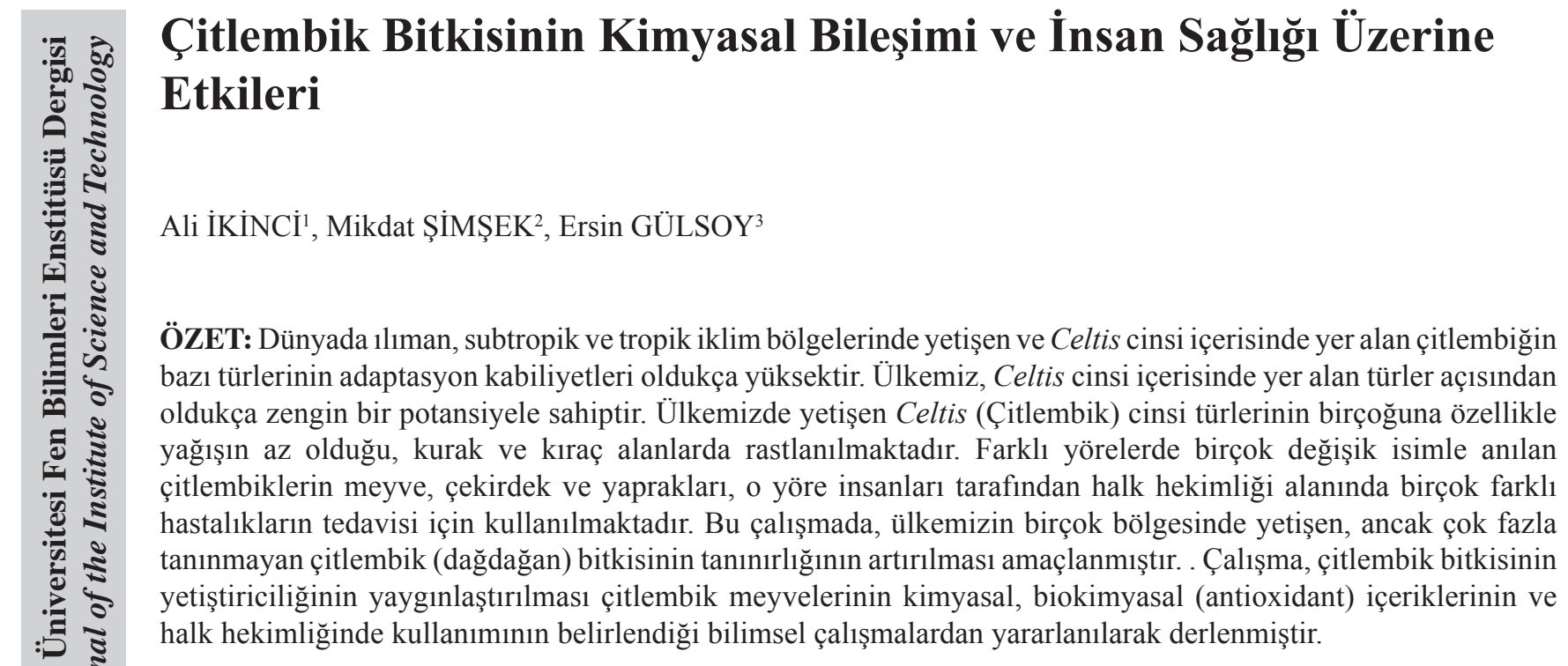

Anahtar Kelimeler: Antioksidanlar, Celtis australis, Celtis tournefortii, dağdağan, fenolik bileşikler, organik asitler.

\section{Chemical Composition of Hackberry Plant and Its Effects on Human Health}

\begin{abstract}
Some species grown in temperate, subtropical and tropical climatic regions around the world and located within the Celtis genus are highly adaptable. Our country has a very rich potential in terms of species in the genus Celtis. Most of the species of Celtis (Hackberry) genus grown in our country are found in the arid and barren areas, especially where there is little rainfall. Fruits, seeds and leaves of hackberry, which have been named with many different names in different regions, are being used by local people for the treatment of many different diseases in the field of folk medicine. In this study, it was aimed to increase the recognition of hackberry (dagdagan) plant grown in many regions of our country, but not too widely known. In order to spread the cultivation of hackberry plant and to evaluate its fruits, chemical contents and the information used in the treatment of diseases were collected using scientific studies on this subject.
\end{abstract}

Keywords: Antioxidants, Celtis australis, Celtis tournefortii, Mediterranean hackberry organic asids, phenolic compounds.

\footnotetext{
Ali İKINCİ (0000-0001-8149-7095), Harran Üniversitesi, Ziraat Fakültesi, Bahçe Bitkileri Bölümü, Şanlıurfa, Türkiye Mikdat ŞİMŞEK (0000-0002-6108-088X), Dicle Üniversitesi, Ziraat Fakültesi, Bahçe Bitkileri Bölümü, Diyarbakır, Türkiye Ersin GÜLSOY (0000-0002-4217-0695), Iğdır Üniversitesi, Ziraat Fakültesi, Bahçe Bitkileri Bölümü, Iğdır, Türkiye Sorumlu yazar/Corresponding Author: Ersin GÜLSOY, ersin116@mynet.com
} 


\section{GİRiş}

Karaağaçgiller (Ulmaceae) familyasında yer alan Celtis cinsi diğer cinslerde olduğu gibi odununun dayanıklı olmasından dolayı, ahşap veya süsleme nitelikleri açısından oldukça değerli ağaçlar meydana getirirler. Celtis cinsi, dünyada 1lıman ve tropikal bölgelerde yetişen 75 'in üzerinde türe sahiptir.

Celtis; her yıl yaprağını döken ve genellikle orta boylu ağaçları içeren bir cinsli, bir evcikli cinstir (Baytop, 1994; Yaltırı, 1998). İngilizcesi European Hackberry, Mediterranean Hackberry ve Nettle-tree olan çitlembik ağaçlarının adaptasyon kabiliyetinin çok yüksek olmaları, kuraklığa, hastalık-zararlılara karşı dayanıklı olmaları ve kazık köke sahip olmalarından dolayı, fakir ve kurak alanların ağaçlandırmalarında kullanılmaktadır.

Yapraklarının mızrak şeklinde ve gri yeşil renkli, taçlarının zarif, dekoratif ve gölge sağlar nitelikte olmasından, özellikle kent alanlarının park ve bahçelerinde süs bitkisi olarak tercih edildikleri, park, bahçe, kamu ve özel yerleşke, site, mezarlık, tarla ve fidanlık gibi tesislerin kuşatılmasında ve sınırlandırılmasında canlı çit olarak kullanılabilecekleri ve etli sulu meyvelerinin başta kuş türleri olmak üzere çeşitli hayvanlar tarafından zevkle tüketildikleri belirtilmektedir (Şekil 1) (Baytop, 1994; Yaltırık, 1998; Yücedağ ve Gültekin, 2008, Özrenk ve ark., 2012). Aynı yazarlara göre; odununun dayanıklı ve esnek olmasından dolayı kasnak, yayık sopası, kaşık, baston, kürek, tarım aletleri yapımı, inşaatlarda, oymacılıkta ve kâğıt yapımında kullanılmaktadır.
Ülkemizde doğal olarak yetişen dört çitlembik türünden Celtis australis L. "adi çitlembik", Celtis glabrata Steven ex Planchón "parlak yapraklı çitlembik", Celtis tournefortii Lam. "doğu çitlembiği”" ve Celtis caucasica ise "Kafkas çitlembiği" olarak isimlendirilmektedir (Çizelge 1).

Ülkemizin değişik yörelerinde doğal olarak yetişen bu çitlembik türlerinin ağaç ve meyveleri çıtlak, çıtlık, çitemek, çitemik, çitlembik, çitlenbek, dadağan, dagum, dağ dağan, dağan, dağdığan, dardağan, dardahan, davılga, davin, davum, dogun, doğdoğan, gıngıres, gıngırez, 1lıç, melengiç ve yabani kiraz olarak adlandırılmaktadır (Baytop, 1994; Yücedağ ve Gültekin, 2008; Demir et al., 2002; Özrenk ve ark., 2012; Anonim, 2014; Anonim, 2018a-f).

Celtis australis L. yuvarlak taçlı, seyrek dallı ve 2025 m’ye kadar boylanabilen ağaçlar oluşturmaktadır. Celtis caucasica Willd.'ın ağaç yüksekliği ise 10-20 m'dir. Celtis glabrata Steven ex Planchón yuvarlak tepeli, sürgünleri tüysüz, parlak, kestane kahverengisi, belirgin beyazımsı lentiselli, 3-5 metre boylarında çalı veya küçük ağaçlara sahiptir. Celtis tournefortii Lam. türü ise tüylü sürgünleri olan, bazı kaynaklarda boyu 2-3 m, bazı kaynaklarda ise 6 m'ye kadar boylanan çalı veya küçük ağaçlar meydana getirmektedir (Özrenk ve ark., 2012; Eminağaoğlu, 2014).

Çitlembikler uzun saplı, bir eşeyli ya da erdişi çiçeklere sahiptirler (Şekil 2). Mart-mayıs ayları arasında çiçek açan ve kışın yaprağını döken bir meyve türü olup, çiçeklerinin albenisinin düşük olmasından dolayı genellikle rüzgarla tozlanmaktadır (Özrenk ve ark., 2012; Eminağaoğlu, 2014).
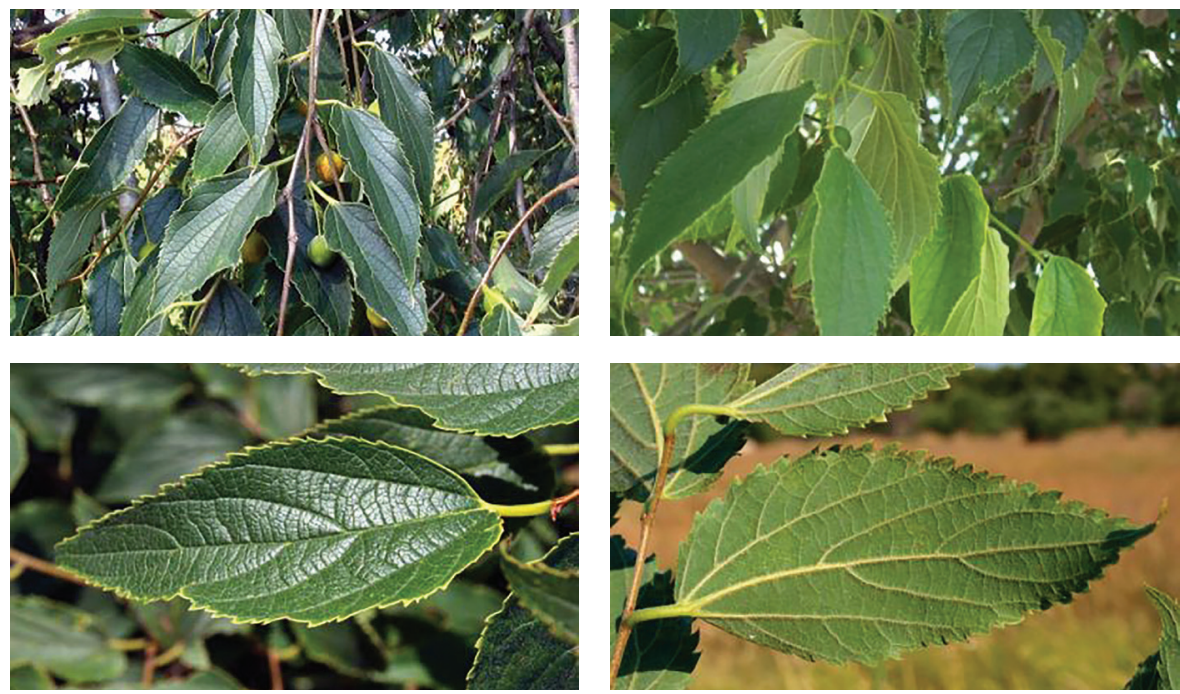

Şekil 1. Çitlembik bitkisinin meyvelerinin ve yapraklarının görünümü (Kaynak: Anonim, 2018g) 
Meyveleri sonbaharda olgunlaşan çitlembiklerden adi çitlembiğin; çekirdekli sulu meyvesi önce yeşil, sonra parlak portakal sarısı ve olgunlaştığında da koyu siyaha yakın bir renk alırken, doğu çitlembiğin çekirdekli sulu meyvesi ise olgunlaştığında sarımtrak kırmızı, kirli sarı veya portakal sarısı renk göstermektedir (Şekil 3, 4 ve 5).
Türlerin nohut büyüklüğünde ve fistık tadında olan meyvelerinin çapı ortalama 9-12 mm'dir. Çekirdeklerinin yüzeyi düz değil, girintili çıkıntılıdır (Yücedağ ve Gülttekin, 2008, Baytop, 1994; Yaltırık, 1998; Özrenk ve ark., 2012; Eminağaoğlu, 2014). Meyve kuru ağırlığının yaklaşık \% 40-50'sini çekirdek oluşturmaktadır.

Çizelge 1. Ülkemizde yaygın olan çitlembik türleri ve bazı özellikleri

\begin{tabular}{|c|c|c|c|c|c|c|c|c|}
\hline $\begin{array}{l}\text { Celtis } \\
\text { Türleri }\end{array}$ & Ömür & Yapı & Çiçeklenme & Habitat & $\begin{array}{l}\text { Yükseklik } \\
\text { (m) }\end{array}$ & Endemik & $\begin{array}{l}\text { Türkiye } \\
\text { Dağılımı }\end{array}$ & $\begin{array}{c}\text { Genel } \\
\text { Dağılımı }\end{array}$ \\
\hline $\begin{array}{l}\text { Celtis } \\
\text { australis }\end{array}$ & $\begin{array}{l}\text { Çok } \\
\text { y1llık }\end{array}$ & A ğaç & $3-5$ & $\begin{array}{l}\text { Çıplak } \\
\text { kayalık } \\
\text { yamaçlar, } \\
\text { nadiren } \\
\text { ormanlar, } \\
\text { çoğu kez } \\
\text { bireysel, } \\
\text { kültür }\end{array}$ & $50-1000$ & $\begin{array}{l}\text { Endemik } \\
\text { değil }\end{array}$ & $\begin{array}{l}\text { Kuzey Batı } \\
\text { Türkiye, } \\
\text { Güney } \\
\text { Anadolu }\end{array}$ & $\begin{array}{l}\text { Kuzey Bat1 } \\
\text { Afrika, Güney } \\
\text { Avrupa, Kuzey } \\
\text { Kafkasya }\end{array}$ \\
\hline $\begin{array}{l}\text { Celtis } \\
\text { caucasica }\end{array}$ & $\begin{array}{l}\text { Çok } \\
\text { y1llık }\end{array}$ & A ğaç & $3-5$ & $\begin{array}{l}\text { Çıplak } \\
\text { kayalık } \\
\text { yamaçlar, } \\
\text { akarsu } \\
\text { ve nehir } \\
\text { kenarları }\end{array}$ & $400-1900$ & $\begin{array}{l}\text { Endemik } \\
\text { değil }\end{array}$ & $\begin{array}{l}\text { Kuzey ve } \\
\text { Güneydoğu } \\
\text { Anadolu }\end{array}$ & $\begin{array}{l}\text { Kafkasya, } \\
\text { Kuzey Irak, } \\
\text { İran, Horasan, } \\
\text { Türkistan, } \\
\text { Afganistan, } \\
\text { Pakistan, Kaşmir }\end{array}$ \\
\hline $\begin{array}{l}\text { Celtis } \\
\text { tournefortii }\end{array}$ & $\begin{array}{l}\text { Çok } \\
\text { y1llık }\end{array}$ & $\begin{array}{l}\text { Çalı } \\
\text { veya } \\
\text { küçük } \\
\text { ağaç }\end{array}$ & $3-4$ & $\begin{array}{l}\text { Çıplak } \\
\text { kayalık } \\
\text { alanlar }\end{array}$ & $300-1500$ & $\begin{array}{l}\text { Endemik } \\
\text { değil }\end{array}$ & $\begin{array}{l}\text { Karasal } \\
\text { Anadolu }\end{array}$ & $\begin{array}{l}\text { Sicilya, } \\
\text { Balkanlar, Girit, } \\
\text { Kuzey Irak, Batı } \\
\text { İran, Güney } \\
\text { Kafkasya }\end{array}$ \\
\hline $\begin{array}{l}\text { Celtis } \\
\text { glabrata }\end{array}$ & $\begin{array}{l}\text { Çok } \\
\text { y1llık }\end{array}$ & $\begin{array}{l}\text { Çalı } \\
\text { veya } \\
\text { küçük } \\
\text { ağaç }\end{array}$ & $3-4$ & $\begin{array}{l}\text { Çıplak } \\
\text { kayalık } \\
\text { yamaçlar }\end{array}$ & $650-1800$ & $\begin{array}{l}\text { Endemik } \\
\text { değil }\end{array}$ & $\begin{array}{l}\text { Kuzey Türkiye, } \\
\text { Karasal } \\
\text { Anadolu, } \\
\text { Güneydoğu } \\
\text { Anadolu }\end{array}$ & $\begin{array}{l}\text { Balkanlar, } \\
\text { Latakya, Kırım, } \\
\text { Kafkasya, Kuzey } \\
\text { Irak, İran }\end{array}$ \\
\hline
\end{tabular}

Kaynak: Anonim (2018a)'dan yararlanılarak hazırlanmıştır.
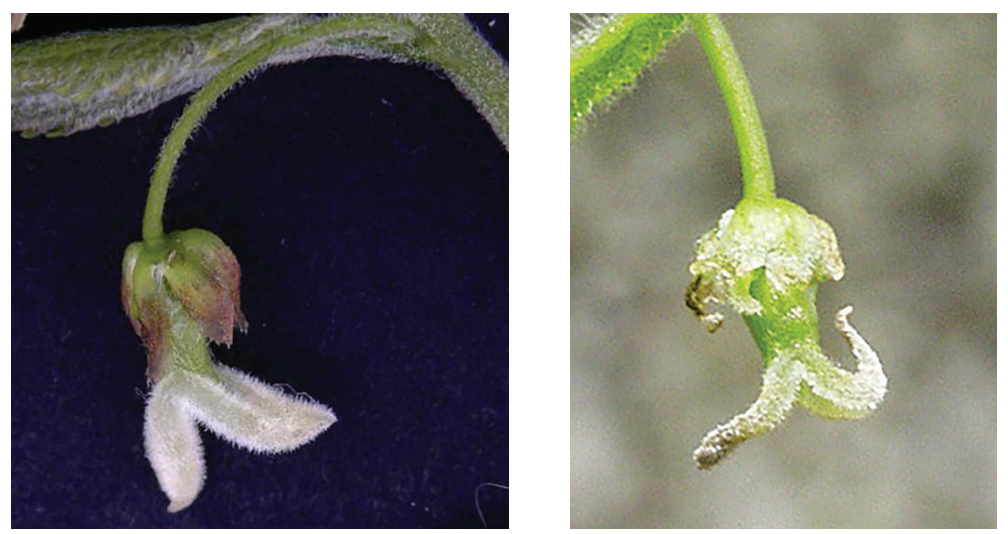

Şekil 2. Çitlembik ağacının çiçeği (Kaynak: Anonim, 2018g-h) 
Meyve, yaprak, tohum ve sakızları halk hekimliğinde ve tıp alanında değişik sağlık sorunlarının giderilmesinde kullanılması yanında, son yıllarda güzel kokulara artan ilgi nedeniyle çitlembikler kozmetik alanında da kullanılmaya başlanmıştır.

Bu çalışmada; ilaç hammaddesi olarak tıp alanında, süs bitkisi olarak kentlerde kullanılan, yapraklarını hayvanların, meyvelerini insanların, hayvanların ve kuşların severek yediği, yakacak olarak, kerestesinin kaliteli oluşundan dolayı mobilya, oymacılık ve değişik araç-gereçlerin yapımında kullanılan çitlembik bitkisinin meyve ve yapraklarının içerikleri ile meyve ve yaprak karışımlarının sağlık alanında kullanımları, yerli ve yabancı literatürlere dayanılarak tartışılmıştır.
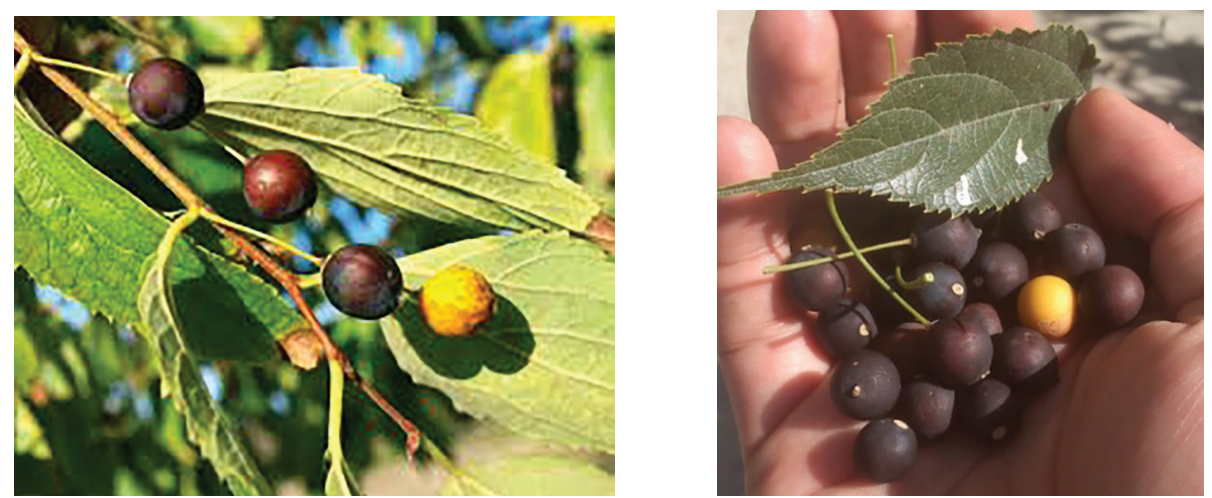

Şekil 3. Adi çitlembik meyveleri (Celtis australis L.) (Kaynak: Anonim, 2018g ve Anonim, 2018i)

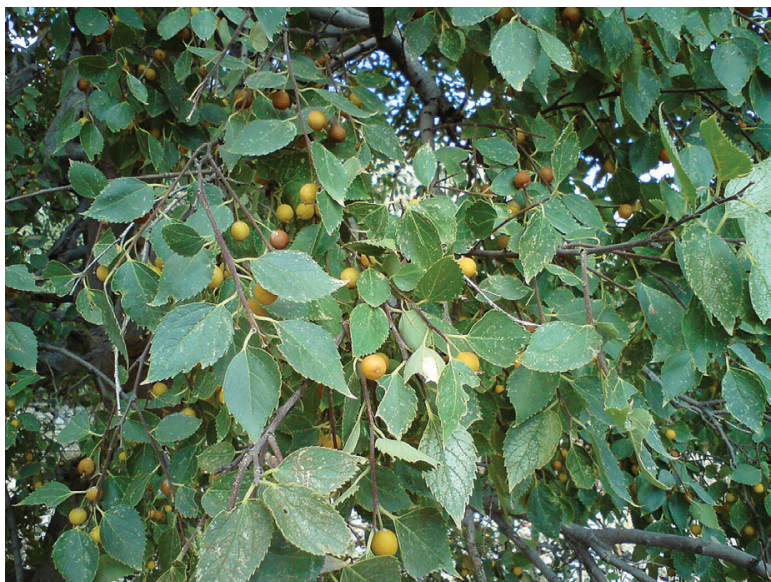

Şekil 4. Doğu çitlembiği (Celtis tournefortii) meyveleri (Kaynak: Anonim, 2018j)

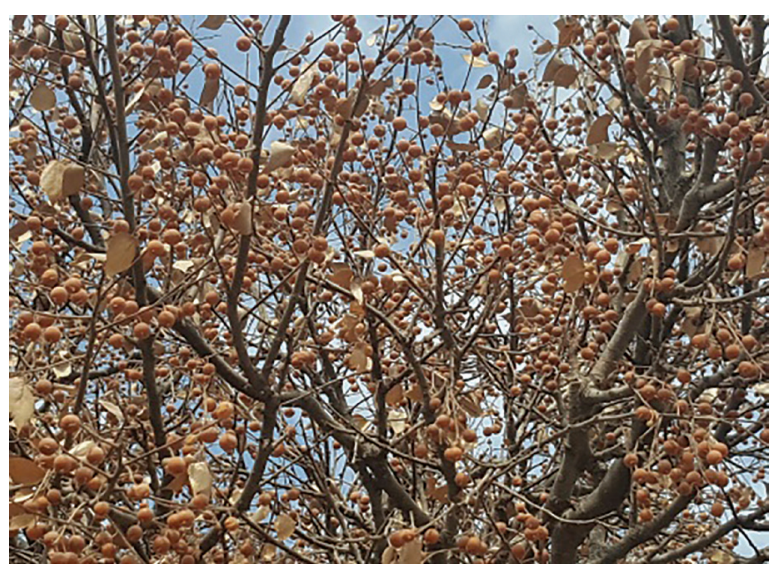

Şekil 5. Doğu çitlembiği (Celtis tournefortii) ağacı ve meyveleri (orijinal) 


\section{Çitlembiğin Kuraklığa Etkileri}

Yapılan çalışmalarda çitlembiğin kuraklığa dayanıklı olmasından dolayı olağan üstü kurak dönemlerde bile hayatta kalabildiği belirtilmiştir (Botta-Dukat and Balogh, 2008).

Nitekim saksı denemesi koşullarında Celtis caucasica fidanlarının şiddetli kuraklık stresi altında morfolojik özellikleri ve su kullanımı üzerindeki etkilerinin araştırıldığı bir çalışmada kuraklık sonrası 2 . ve 4. günde morfolojik olarak bitki çapı, yaprak sayısı, yaprak alanı, sürgün ve kök uzunluğu, köklerin taze ve kuru ağırlığı, yaprak ağırlığı gibi bazı parametreler ölçülmüştür.

Sonuçlar kurak şartlar altında yetiştirilen ağaçlarda ikinci ve üçüncü ayda ortalama yaprak alanı ve sayısında, yaprak alanı ve sürgün uzunluğu arasında kuraklığın 30 ve 40 . gününde $\% 5$ seviyesinde önemli sonuçlar elde edilmiştir. Bu türün kurak şartlar altında hayatta kalabildiği ancak arazi şartlarında kurak şartlar altında yetişen ağaçlar üzerinde bu tür araştırmaların yapılması gerektiği vurgulanmıştır (Tabatabae, et al., 2014; Tabatabae et al., 2017).

\section{Çitlembiğin İnsan Sağlığı Üzerine Etkileri}

Çitlembik bitkisinin yaprak, meyve, çekirdek, ağaç kabuğu ve sakızının insan sağlığı açısından önemi üzerine aşă̆ıda yer alan bilgiler, çitlembik bitkisi ile ilgili çeşitli web sayfalarından ve bu konuda yapılmış bilimsel çalışma sonuçların derlenmesiyle hazırlanmıştır.

Çitlembik ağacının meyveleri mercimekten az büyük ve buruk fıstık tadındadır. Meyvesi, yaprakları, tohumları ve sakızı hekimlikte kullanılır. E ve B grubu vitaminlerce zengindir. İçeriğinde potasyum, sodyum, fosfor, kalsiyum, çinko ve mangan gibi mineraller bulunmaktadır. Ayak terlemelerini keser. Yaraları tedavi eder. İdrar söktürür. Dalak için çok yararlıdır. Böbrek kumlarının dökülmesine yardımcı olur. Ağızdan akan suların kesilmesini sağlar. Midedeki müzmin ağrılarını giderir. Öksürüğü keser. Meyvesi hafif müshil etkilidir. Yaprakları saçlara sürüldüğünde saçları siyahlaştırır. Vücudu şişmanlatır. Çitlembik tohumlarından çok lezzetli bir kahve yapılır (Şekil 6). Ayrıca, çitlembik yağı çıkarılır (Şekil 7) (Anonim, 2018e; Anonim 2018f, Anonim, 2018k, Anonim, 20181).

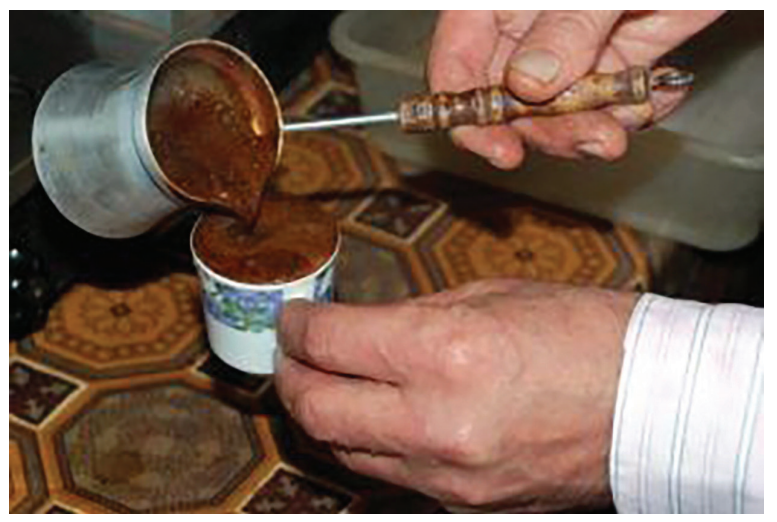

Şekil 6. Hakkari'de çitlembik meyvesinden üretilmeye başlanan dağdağan kahvesi (Kaynak: Anonim, 2018m)
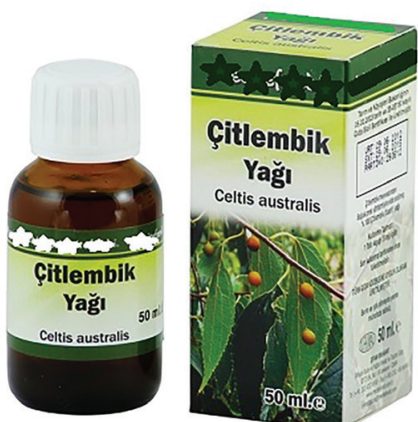

Şekil 7. Çitlembik bitkisinden elde edilmiş çitlembik yapı (Kaynak: Anonim, 2018n) 
Erzincan ve yöresinde dağdağan olarak bilinen doğu çitlembiği meyveleri ezilerek ve içine fındık ya da ceviz eklenerek "döğmeç" adı verilen bir besin olarak değerlendirilmektedir (Özrenk ve ark. 2012).

Öksürük ve bronşit tedavisinde; çitlembik sakızı ve tohumları balla macun yapılarak yenilir. Çitlembik yaprakları suyla kaynatılıp, balla tatlandırılarak içilmesinin de tedaviye önemli katkısı olur.

Mide ülseri için bitkinin sakızı balla macun yapılarak aç karnına birer tatlı kaşı $\breve{g} ı$ yenilir. Diğer etkiler için tohumları dövülerek bal ile macun yapılarak yenilir. Yaprakları da kaynatılarak balla tatlandırılarak içilir.

Çitlembik meyvelerinin yüksek şeker içeriğine sahip olduğu ve şeker oranının \% 81.5 > kadar yükseldiği bildirilmiştir (Ota et al., 2017). Ağrı kesici etkisi olması, müzmin mide ağrılarını dindirmesi, antiseptik etkisi nedeniyle yaraların iyileşmesini sağlamada ve kum dökümünde etkili olması gibi birçok özellikleri nedeniyle tıbbi olarak çok etkili olduğu düşünülmektedir (Chevallier 1996; Yücedağ ve Gültekin, 2008; Ota et al., 2017; Özrenk ve ark., 2012). Çitlembik yaprak ve meyve karışımları; adet görememe (amenore), kolik (uzun ve yoğun bebek ağlaması), ishal, dizanteri, peptik ülser ve adet kanamasının tedavisinde koruyucu etkilere sahiptir (Chevallier 1996; Ota et al., 2017). “Çin'in Trbbi Bitkileri” isimli kitaba göre de, çitlembik ağır menstrüel kanama (adet kanaması), amenoresi (adet görememe) ve kolik (uzun ve yoğun bebek ağlaması) gibi bazı hastalıkları tedavi etmektedir. Çitlembiklerin analjezik (ağrı kesici) etkisi bulunmaktadır. Çitlembikler mide mukoza zarlarını büzerek peptik ülseri tedavi etmekte, ishal ve dizanteriyi de tedavi ettiği iddia edilmektedir. Amerika Yerlileri boğaz ağrısının tedavisinde, çocuk doğum ve zührevi hastalıkların tedavisinde çitlembik kabuğunu (ağaç veya dal kabuğu) kullanmaktadırlar (Anonim, 2018o).
Bilim insanları yaptıkları çalışmalarla çitlembik ağacı yapraklarının yararlarını gözler önüne sermişlertir: Scientia Pharmaceutica dergisinde yayınlanan bir makalede, Misır'lı bilim insanları çitlembik yapraklarının önemli antioksidan ve sitotoksik özellikler içerdiğini göstermişlerdir. İlgili makalede, çitlembik yapraklarında belirlenen bu bileşiklerin yaşlanmaya karşı ve kanser önleme özelliği olduğu belirtilmiştir (Anonim, 2018o).

Amerikan Spor ve Tip Koleji'nde yayınlanan bir araştırma makalesinde de çitlembik kabuğunun antikanser özellikleri ile bilinen quercetin bileşiğini içerdiği bildirilmiştir. Anticancer Agents in Medicinal Chemistry dergisinde 2013 yllında yayınlanan bir başka çalışmada ise quercetin'in kanser hücrelerindeki aktiviteyi inhibe ettiği tespit edilmiştir. Çalışmada ayrıca, quercetin'in iltihabı ve aterosklerozu (damar sertliği) giderme kabiliyetine dikkat çekilmiştir (Anonim, 2018o).

Çitlembik Bitkisinin Meyve, Çekirdek ve Yapraklarının Bileşenleri ve Besleyici Özellikleri

Demir et al., (2002) \%50 nem içeriğine sahip çitlembik (Celtis australis L.) meyvelerinde meyve çapı, meyve boyu ve meyve hacmini sırasıyla; 9.47 $\mathrm{mm}, 10.73 \mathrm{~mm}$ ve $448.36 \mathrm{~mm}^{3}$ olarak tespit etmişlerdir. Araştırıcılar, \%15.25 ve \%50.42 nem içeriğine sahip çitlembik meyvelerinde, 1000 meyve ağırlı̆̆ının 247.5 g ile $594 \mathrm{~g}$ arasında değiştiğini belirlemişlerdir.

Ota et al., (2017) olgunlaşmış çitlembik meyve etinin \%30.0, hava ile kurutulmuş tohumların \%18.1 oranında su içerdiğini (Çizelge 2); buna karşıllı meyvelerin $3.4 \mathrm{~g} / 100 \mathrm{~g}$ protein, $\% 10.2$ toplam diyet lifi, \% 8.2 çözünmez lif ve \%2.0 çözünür lif içerdiğini bildirmişlerdir. Demir et al., (2002), çitlembik meyvelerinin ham yağ, ham protein, ham lif, ham enerji ve kül içeriğini sırasıyla; \%6.70, \%19.32, \%4.40, 16.2 $\mathrm{kcal} / \mathrm{g}$ ve $\% 15.29$ olarak belirlemişlerdir.

Çizelge 2. Hava ile kurutulmuş çitlembik meyve eti ve tohumlarında su, suda çözünebilir kuru madde miktarı, indirgen şekerler ve toplam yağ miktarı

\begin{tabular}{lcc}
\hline Analiz & Meyve eti & Tohumlar \\
\hline Su (\%) & 30.0 & 18.1 \\
Suda çözünebilir kuru madde (\% Brix) & 53.4 & 0.98 \\
İndirgen şekerler (g/10 g yaş ağırlık) & 50.9 & - \\
Toplam yağ (g/10 g kuru ağırlık) & - & 8.1 \\
\hline
\end{tabular}

Kaynak: Ota et al., (2017)'den alınmışıır. 
Çitlembik Bitkisinin Meyve, Çekirdek ve Yapraklarının Mineral Element Bileşimi

Ota et al., (2017), çitlembik yapraklarının-, meyvelere kiyasla 20 kat daha fazla Ca $\left(5.97{\left.\mathrm{~g} 100 \mathrm{~g}^{-1}\right)}^{-1}\right.$ içerdiğini, kalsiyumun çitlembik yapraklarında en fazla bulunan element olduğunu, bunu Silisyum ( $\mathrm{Si}$ ) ve potasyumun (K) izlediğini belirlemişlerdir (Çizelge 3). Aynı çalışmada, araştırıcılar çitlembik meyvelerinde $\mathrm{Si}$ tesbit edilemediğini de belirtmişlerdir.

Ota et al., (2017) tarafından çitlembik meyve etinde mikro elementlerin belirlenmesi amaciyla yapılan çalışmada, en fazla bulunan mikro element $\mathrm{Fe}$
$5.05 \mathrm{mg} 100 \mathrm{~g}^{-1}$ olurken, bunu, Mn (1.20 mg $\left.100 \mathrm{~g}^{-1}\right)$

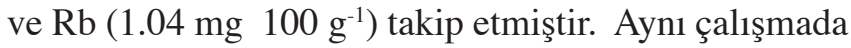
$\operatorname{Br}\left(0.69 \mathrm{mg} 100 \mathrm{~g}^{-1}\right), \mathrm{Cu}\left(0.45 \mathrm{mg} 100 \mathrm{~g}^{-1}\right)$ ve $\mathrm{Zn}(0.35$ mg $\left.100 \mathrm{~g}^{-1}\right)$ düşük konsantrasyonlarda tespit edilmiştir (Çizelge 3).

Demir et al., (2002) tarafından yapılan bir çalışmada çitlembik meyvesinin morfolojik özellikleri ve besin elementleri içerikleri belirlenmiştir. Çalışmada $\mathrm{Na}, \mathrm{P}, \mathrm{K}$, $\mathrm{Fe}, \mathrm{Zn}, \mathrm{Mn}, \mathrm{Ca}, \mathrm{B}, \mathrm{Ba}, \mathrm{Mg}$ ve $\mathrm{Sr}$ içerikleri sırasıyla; $59.52 \mathrm{mg} \mathrm{kg}^{-1}, 1519.59 \mathrm{mg} \mathrm{kg}^{-1}, 3523.66 \mathrm{mg} \mathrm{kg}^{-1}, 21.37$ ppm, 3.46 ppm, 22.50 ppm, 43973.09 ppm, 64.4 ppm, $264.42 \mathrm{ppm}, 6732.5 \mathrm{ppm}$ ve $234.62 \mathrm{ppm}$ olarak tespit edilmiştir.

Çizelge 3. Çitlembik meyve eti ve yapraklarının mineral madde içerikleri

\begin{tabular}{|c|c|c|c|}
\hline \multirow{2}{*}{ Element } & \multirow{2}{*}{$\begin{array}{c}\begin{array}{c}\text { Meyve eti } \\
\left(\mathrm{mg} 100 \mathrm{~g}^{-1}\right)\end{array} \\
\text { Ekim }\end{array}$} & \multicolumn{2}{|c|}{$\underset{\left(\mathrm{mg} \mathrm{100} \mathrm{g}^{-1}\right)}{\text { Yaprak }}$} \\
\hline & & Haziran & Ekim \\
\hline $\mathrm{Si}$ & Belirlenmedi & 1280 & 2570 \\
\hline $\mathrm{P}$ & 143 & 141 & 131 \\
\hline $\mathrm{S}$ & 20.8 & 102 & 84 \\
\hline $\mathrm{Cl}$ & 71 & 240 & 343 \\
\hline K & 1060 & 834 & 975 \\
\hline $\mathrm{Ca}$ & 269 & 5970 & 5590 \\
\hline $\mathrm{Mn}$ & 1.2 & 6.0 & 11.8 \\
\hline $\mathrm{Fe}$ & 5.1 & 11.4 & 17.8 \\
\hline $\mathrm{Ni}$ & 0.25 & 0.24 & 1.72 \\
\hline $\mathrm{Cu}$ & 0.45 & 1.09 & 2.01 \\
\hline $\mathrm{Zn}$ & 0.35 & 0.79 & 1.03 \\
\hline $\mathrm{Se}$ & 0.09 & 0.08 & 0.34 \\
\hline $\mathrm{Pb}$ & 0.07 & 0.16 & 0.70 \\
\hline $\mathrm{Br}$ & 0.69 & 0.96 & 2.01 \\
\hline $\mathrm{Rb}$ & 1.04 & 0.32 & 0.56 \\
\hline $\mathrm{Sr}$ & 0.50 & 6.00 & 5.92 \\
\hline Mo & 0.04 & 0.04 & 0.17 \\
\hline
\end{tabular}

Kaynak: Ota et al., (2017)

Çitlembik meyvelerinde ana mineraller olarak $\mathrm{Na}$, $\mathrm{K}, \mathrm{P}, \mathrm{Mn}, \mathrm{Ca}, \mathrm{B}, \mathrm{Ba}, \mathrm{Mg}$ ve Se'un bulunduğu, yerfistığı, kuşburnu ve mersin (Myrtus communis L.) meyvelerine kıyasla meyvelerinin $\mathrm{Na}, \mathrm{K}, \mathrm{P}, \mathrm{Ca}, \mathrm{Mg}, \mathrm{Mn}$ ve $\mathrm{Zn}$ içeriklerinin, daha yüksek olduğu bildirilmiştir (Baryeh, 2001; Demir and Özcan, 2001; Demir et al., 2002). 
Erzincan yöresinden toplanan doğu çitlembiğ (Celtis tournefortii Lam.) meyvelerinin meyve eti k1sımlarında bulunan besin elementlerinin içerik bakımından siralamasının $\mathrm{Ca}>\mathrm{Mg}>\mathrm{K}>\mathrm{N}>\mathrm{P}>\mathrm{Fe}>\mathrm{Mn}>\mathrm{Zn}>\mathrm{Cu}$ şeklinde olduğu, buna karşın çekirdek kısmında ise $\mathrm{Ca}>\mathrm{Mg}>\mathrm{N}>\mathrm{K}>\mathrm{P}>\mathrm{Fe}>\mathrm{Mn}>\mathrm{Zn}>\mathrm{Cu}$ şeklinde olduğu tespit edilmiştir (Özrenk ve ark., 2012).

\section{Çitlembiğin Organik Asit İçeriği}

Doğu çitlembiği (Celtis tournefortii Lam.) meyve etinin organik asit içeriğinin, çekirdek kısımlarının organik asit içeriğine göre daha yüksek olduğu belirlenmiştir. Erzincan yöresinden toplanan doğu çitlembiği (Celtis tournefortii Lam.) meyve etinde okzalik asit, sitrik asit, malik asit ve süksinik asit miktarları sırasıyla; $1.42 \mathrm{~g} \mathrm{~kg}^{-1}, 63.59 \mathrm{~g} \mathrm{~kg}^{-1}, 53.82$ $\mathrm{g} \mathrm{kg}^{-1}, 7.46 \mathrm{~g} \mathrm{~kg}^{-1}$ olarak tespit edilmiştir. Yapılan bu araştırmada; meyve etindeki hakim organik asidin sitrik asit (63.59 $\left.\mathrm{g} \mathrm{kg}^{-1}\right)$ ve çekirdekteki hakim organik asidinin ise malik asit $\left(12.97 \mathrm{~g} \mathrm{~kg}^{-1}\right)$ olduğu belirlenmiştir (Özrenk ve ark., 2012).

\section{Çitlembiğin Şeker ve C Vitamini İçeriği}

Doğu çitlembiği (Celtis tournefortii Lam.) meyve eti ve çekirdeklerinin şeker içeriklerine bakıldı ̆̆ında; glikozun (\% 9.96-0.84), fruktoz (\% 8.51-0.72) ve sakkarozdan (\% 0.26- 0.12 ) daha yüksek olduğu tespit edilmiştir. Şeker içerikleri bakımından (glikoz, fruktoz, sakkaroz) meyve etinin, çekirdeğe kıyasla daha yüksek içeriğe sahip olduğu görülmüştür. Aynı araştırmada, doğu çitlembiği (Celtis tournefortii Lam.) meyve etinin $2.29 \mathrm{mg} / 100 \mathrm{~g}$ ve çekirdeğinin ise $1.25 \mathrm{mg}$ 100g-1 C vitamini içerdiği tespit edilmiştir (Özrenk ve ark., 2012).

\section{Çitlembiğin Yă̆ Asidi Bileşimi ve Tokoferol İçeriği}

Erzincan yöresinde yapılan bir çalışmada Doğu çitlembiği (Celtis tournefortii Lam.) meyvelerinin kabuk, kabuktan sonraki kısım (mezokarp) ve iç kısımdaki (çekirdek) yağ asitleri miktarları ve tokoferol miktarları belirlenmiştir (Çizelge 4). Yapılan bu çalışmada, doğu çitlembiği meyvelerinin meyve kabuk arası (mezokarp) kısımdaki palmitik asit miktarı $\% 5.42$, palmitoleik asit miktarı \%0.14, stearik asit miktarı \%2.95, oleik asit miktarı \%17.18, linoleik asit miktarı \%72.72, linolenik asit miktarı $\% 0.50$ ve arakhidik asit miktarı \%0.27 olarak tespit edilmiştir (Özrenk ve ark., 2012).

Slovenya'da yapılan bir araştırmada, çitlembik (Celtis australis L.) tohumunun 100 gramında $5.11 \mathrm{~g}$ yağ asidi bulunurken, bu yağ asitlerinin \%76.25>ini ise linoleik asit içermektedir (Ota et al., 2017). Geriye kalan ana yă asitleri ise oleik asit $\left(0.951{\mathrm{~g} 100 \mathrm{~g}^{-1}}^{-1}\right.$ tohum, \%14.18), palmitik asit $\left(0.452951{\mathrm{~g} 100 \mathrm{~g}^{-1}}^{-1}\right.$ tohum, \% 6.72) ve stearik asit $\left(0.188951{\mathrm{~g} 100 \mathrm{~g}^{-1}}^{-1}\right.$ tohum; \% 2.81)'tir (Ota et al., 2017).

Çizelge 4. Doğu çitlembiği meyvelerinin farklı kısımlarındaki yağ asitleri içerikleri (\%)

\begin{tabular}{llllllll}
\hline $\begin{array}{l}\text { Meyve } \\
\text { Kısımları }\end{array}$ & $\begin{array}{l}\text { Palmitik } \\
\text { Asit }\end{array}$ & $\begin{array}{l}\text { Palmitoleik } \\
\text { Asit }\end{array}$ & $\begin{array}{l}\text { Stearik } \\
\text { Asit }\end{array}$ & $\begin{array}{l}\text { Oleik } \\
\text { Asit }\end{array}$ & $\begin{array}{l}\text { Linoleik } \\
\text { Asit }\end{array}$ & $\begin{array}{l}\text { Linolenik } \\
\text { Asit }\end{array}$ & $\begin{array}{l}\text { Arakhidik } \\
\text { Asit }\end{array}$ \\
\hline Kabuk & 6.02 & 0.11 & 2.78 & 23.54 & 64.93 & 1.24 & 0.32 \\
Meyve eti & 5.42 & 0.14 & 2.95 & 17.18 & 72.72 & 0.50 & 0.27 \\
Çekirdek & 9.20 & 0.54 & 4.11 & 64.47 & 17.68 & 1.74 & 0.40 \\
\hline
\end{tabular}

Kaynak: Özrenk ve ark., (2012)'dan değiştirilmeden alınmıştır.

\section{Doğu çitlembiği (Celtis tournefortii Lam.)} meyvelerinde en yüksek alfa tokoferol miktarının çekirdekte $\left(21.20 \mathrm{mg} \mathrm{kg}^{-1}\right)$, en yüksek gamma tokoferol (135.98 $\mathrm{m} \mathrm{k} \mathrm{kg}^{-1}$ ) ile en yüksek delta tokoferol miktarının ise meyve etinde $\left(2.18 \mathrm{mg} \mathrm{kg}^{-1}\right)$ olduğu belirlenmiştir (Özrenk ve ark., 2012).

\section{Toplam Fenolik Bileşikler-}

Slovenya'da yapılan bir araştırmada, olgunlaşmamış çitlembik (Celtis australis L.) meyve

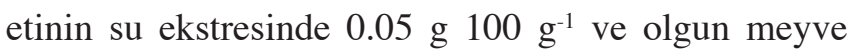

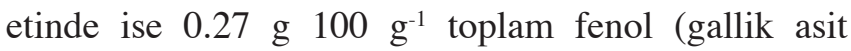
eşdeğeri olarak) bulunduğu belirlenmiştir (Ota et al., 
2017). Aynı çalışmada, olgun çitlembik meyvelerinin etanol ekstraksiyonunda belirlenen toplam fenoller

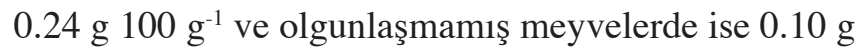
$100 \mathrm{~g}^{-1}$ olarak tespit edilmiştir.

Ota et al., (2017) Slovenya'da yaptıkları bir araştırmada, ekim ayı sonunda toplanan çitlembik

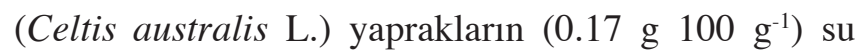
ekstrelerinin, haziran sonunda toplanan yapraklardan

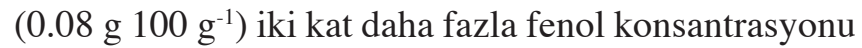
sahip olduğunu tespit etmişlerdir.

Otaet al., (2017), olgunlaşmamış ve olgun çitlembik meyve etinde siyanidin-3,5-di- $O$-glikozit'in en fazla bulunan fenolik bileşik olduğunu, bunu pelargonidin3,5-di-O-glikosit ve 3,5-dihydroxybenzaldehyde'in izlediğini belirtmişlerdir. Araştırıcılar; olgunlaşmış meyve etinin, olgunlaşmamış meyve etine göre 10 kat daha fazla fenol içerdiğini bildirmişlerdir.

\section{Antioksidan Aktivite}

Çitlembik ağaçlarından ekim ayı sonunda toplanan yaprakların, haziran sonunda toplanan yapraklara göre 50 kat daha fazla antioksidan içerdiği tespit edilmiştir (Ota et al., 2017). Araştırıcılar, çitlembik yapraklarında, Haziran $\left(0.133 \mathrm{mg} 100 \mathrm{~g}^{-1}\right.$ yaş ağırlık) ayına göre, ekim (13.522 mg $100 \mathrm{~g}^{-1}$ yaş ağırlık) ayında 100 kat artan epikateşinin, yapraklardaki antioksidan içeriği artışında esas rolü oynadığını tespit etmişlerdir.

\section{Antifungal Etkisi}

Çitlembik yapraklarından hazırlanan etanol ekstraktlarının en önemli fırsatçı fungal patojen olan Candida albicans'a ve ortaya çıkan maya benzeri

\section{KAYNAKLAR}

Anonim, 2014. Çitlembik (Dağan, Çıtlık, Dağdağan). T. C. Orman ve Su İşleri Bakanlığı Orman Genel Müdürlüğü, Geniş Yapraklı ve Meyveli Türlere Ait Tohum Bahçeleri Tesisi Eylem Planı (2014-2018), sayfa 17-19, Ankara.

Anonim, 2018a. Türkiye bitkileri veri servisi (TÜBIVES). http:// www.tubives.com/index.php (Erişim tarihi: 30 Ocak, 2018).

Anonim, 2018b. Mardin'de “gıngırez” vakti. https://www. instagram.com/p/97-1cvSrzp/ (Erişim tarihi: 28 Ocak 2018).

Anonim, 2018c. Köy çocuklarının gıngıres (dağdığan) eğlencesi. http:// www.haldeh. com/index. php?option=com_ content\&view $=$ article \& id= 547\%3Akoy-cocuklariningingires-dagdigan-eglencesi\&Itemid $=86$ (Erişim tarihi: 30 Ocak 2018). mantar olan iki fırsatçı patojene (Candida parapsilosis ve Rhodotorula mucilaginosa) karşı antimikrobiyal ve özellikle antifungal etkinlikleri tespit edilmiştir (Ota et al., 2017).

\section{SONUÇ}

Küresel 1sınmaya bağlı olarak dünyada ve ülkemizde su kıtlığının yaşanmaya başladığı günümüzde, kuraklığa dayanıklı türlere olan ihtiyaç giderek artmaktadır. Son yıllarda ülkemiz ormancılık çalışmalarında, ülkemizin biyolojik çeşitliliğine büyük katkı sağlayacak yabanıl meyveli ağaç türlerinin başarılı şekilde kullanılmaya başlanmış olması memnuniyet verici bir gelişmedir. Kazık kök sistemine sahip olması nedeniyle kuraklığa ve ayrıca hastalık-zararlılara dayanıklı olan çitlembik bitkisinin, ülkemiz ormancılık çalışmalarında kullanımının yaygınlaştırılması gerekmektedir. Ülkemiz, birçok çitlembik türünün gen merkezi konumunda olup, çitlembikler bakımından çok zengin bir biyoçeşitliliğe sahiptir. Sahip olduğumuz bu zenginliğin yeterince değerlendirilmesi, ancak insan beslenmesinde ve sağlığında kullanılabilecek meyveli türlere gereken önemin verilmesiyle mümkün olacaktır. Bu çalışmada da görülmüştür ki; çitlembik, zengin kimyasal içeriğe ve besin elementlerine sahip bir bitkidir. Unutulmaya yüz tutan çitlembik bitkisinin gen kaynaklarının korunması ileriki, ıslah çalışmalarına materyal oluşturması bakımından ayrıca meyve, yaprak, tohum ile kabuklarının özellikle insan sağlığ ve halk hekimliğinde faydalı kullanımı göz önüne alındığında yakın gelecekte kullanım alanı yaygınlaşacaktır.

Anonim, 2018d. Meyvesini saklayan ağaç. http://www.yuksekova. bel.tr/meyvesini-saklayan-agac-3135h.htm (Erişim tarihi: 29 Ocak 2018).

Anonim, 2018e. Çitlenbik ve çitlembiğin faydaları. https:// sifavebitki. wordpress.com /2015/01/30/ citlenbik-vecitlembigin-faydalari (Erişim tarihi: 28 Ocak 2018).

Anonim, 2018f. Çitlenbik ve çitlembiğin faydaları.http://sifavebitkii. blogspot.com.tr/2015/01/citlenbik-ve-citlembigin-faydalar. html_(Erişim tarihi: 28 Ocak 2018).

Anonim, 2018g. Celtis australis L. http://luirig. altervista.org/ schedenam/ fnam.php?taxon= Celtis+ australis (Erişim tarihi: 31 Ocak 2018). 
Anonim, 2018h. Celtis occidentalis L. (Hackberry). Virginia Tech Dendrology. http://dendro.cnre.vt.edu/dendrology/syllabus/ factsheet.cfm?ID=26 (Erişim tarihi: 31 Ocak 2018).

Anonim, 2018i. Adi çitlenbik (Celtis australis L.) meyvesi. http:// www.fidandeposu.com/citlik-adi-citlenbik-celtis-australisfidani (Erişim tarihi: 31 Ocak 2018).

Anonim, 2018j. Celtis tournefortii. https://en.wikipedia.org/wiki/ Celtis tournefortii (Erișim tarihi: 31 Ocak 2018).

Anonim, 2018k. Celtis australis, adi çitlenbik, dağdağan. https:// www.1001 fidan.com/celtis-australis-adi-citlenbik-dagdagancitlembik-fidani-432 (Erişim tarihi: 29 Ocak 2018).

Anonim, 20181. Çitlenbik (Celtis) nedir? Faydaları nelerdir? http://www.bitkicenter.com/citlenbik-celtis-nedir-faydalarinelerdir/ (Erişim tarihi: 30 Ocak 2018).

Anonim, 2018m. Hakkâri'nin 'dağdağan kahvesi' Türkiye'ye açılacak. https:// www.sondakika. com/haber/haber-hakkarinin-dagdagan-kahvesi-turkiye-ye-acilacak-4019414/ (Erişim tarihi: 30 Ocak 2018).

Anonim, 2018n. Macitefendi çitlembik yă̆ı. http://www. botanikecza.com/Mecitefendi-Citlembik-Yagi-50cc_15533. html (Erişim tarihi: 30 Ocak 2018).

Anonim, 2018o. All about hackberry in India. http://theindianvegan. blogspot.com.tr/2012/10/all-about-hackberry-in-india.html (Erişim tarihi: 30 Ocak 2018).

Baryeh EA, 2001. Physical properties of bambara groundnuts. Journal of Food Engineering, 47(4), 321-326.

Baytop,T, 1994. Türkçe bitki adları sözlüğü. Turk Dil Kurumu Yayınları, No: 5678, Ankara.

Boydak M, 1988. Türkiye'de yeni tespit edilen iki çitlenbik (Celtis australis L.) ormanı. İ. Ü. Orman. Fakültesi Dergisi, Seri A, 38(1): 48-59.

Botta-Dukát Z, Balogh L, 2008. The most important invasive plants in Hungary. HAS Institute of Ecology and Botany

Chevallier A, 1996. The encyclopedia of medicinal plants: A practical reference guide to over 550 key herbs and their medicinal uses. Dorling Kindersley, London, 336 s.
Demir F, Doğan H, Özcan M, Haciseferoğullari H, 2002. Nutritional and physical properties of hackberry (Celtis australis L.). J. Food Eng., 54: 241-247.

Eminağaoğlu Ö, 2014. Celtis L. Türkiye'nin doğal-egzotik ağaç ve çalıları I. (Editör: Akkemik, Ü.). Orman Genel Müdürlüğü Yayınları, MRK Baskı ve Tanıtım., Ankara, s: 408-412.

Gültekin HC, 2010. Kapalı tohumlu (angiospermae) ağaç ve çalıların eşey özellikleri el kitabı. Ankara, s. 63-64.

Ota A, Višnjevec AM, Vidrih R, Prgomet Ž, Nečemer M, Hribar J, Cimerman NG, Možina SS, Bučar-Miklavčič M, Ulrih NP, 2017. Nutritional, antioxidative, and antimicrobial analysis of the Mediterranean hackberry (Celtis australis L.). Food Science \& Nutrition, 5(1):160-170.

Özcan M, Akbulut M, 1998. Some physical and chemical properties of myrtle (Myrtus communis L.) fruits. Gida, 23, 121-123.

Özrenk K, Gündoğdu M, Türkoğlu N, Gazioğlu Şensoy Rİ, 2012. Erzincan yöresinde doğal olarak yetişen doğu çitlembiği (Celtis tournefortii Lam.) meyvelerinin bazı kimyasal özellikleri. Yüzüncü Yıl Üniversitesi Tarım Bilimleri Dergisi, 22 (1): 26-32.

Tabatabaei SA, Jalilvand H, Ahani H, 2014. Drought stress response in caucasian hackberry: growth and morphology. Journal of Biodiversity and Environmental Sciences (JBES).Vol.5, No.3, p.158-169.

Tabatabaei SA, Sharif ME, Bagheri M, Jalilvand H, Ahani H, 2017. Morphological adaptation of Cercis griffithii seedlings in response to progressive drought and salinity stresses. Journal of Applied Sciences and Environmental Management, 21(7), 1262-1267.

Yaltırık F, 1998. Dendroloji ders kitabı II, Angiospermae (Kapalı Tohumlular), İ.Ü. Yayın No: 4104, Orman Fakültesi Yayın No: 420, İstanbul.

Yücedağ C, Gültekin HC, 2008. Adi çitlembik (Celtis australis L.) ve doğu çitlenbiği (Celtis tournefortii Lam.) tohumlarının çimlenmesi üzerine araştırmalar. Süleyman Demirel Üniversitesi, Fen Bilimleri Enstitüsü Dergisi, 12(3): 182-185. 